\title{
Identifikace plošného zemědělského znečištění s využitím termografického snímkování
}

\section{ŠTĚPÁN MARVAL, TOMÁŠ HEJDUK, ANTONÍN ZAJÍČEK, TOMÁŠ VYBÍRAL, RADEK ROUB, MARKÉTA KAPLICKÁ}

Klíčová slova: jakost vody - teplota vody - zdroj znečištění - stavba odvodnění - drenážní výust'

\section{SOUHRN}

Sledování jakosti vody v České republice (ČR) nemá tak dlouhou tradici jako sledování jejího množství, a to i přesto, že pro společnost, průmysl i zemědělství je kvalita vodních zdrojů strategická. Pro šiření znečištění ze zemědělské činnosti je významný podpovrchový odtok. S podpovrchovým (drenážním) odtokem je spojováno především vyplavování dusičnanů, pesticidů a dalších ve vodě rozpustných látek (fosforečnany) aplikovaných na zemědělskou půdu. Stavby zemědělského odvodnění byly $v$ minulosti budovány za účelem podpory a rozvoje zemědělství. Jejich tradice $v$ ČR sahají do konce 19. století, nejintenzivněji však byly realizovány v období do 2. světové války, později pak v letech 1960-1990. Odvodňovací stavby na zemědělských pozemcích byly navrhovány jako jednoúčelové k odvádění přebytku vody z pozemku. Se zvyšujícím se výskytem hydrologických extrémů (zejména sucha, ale i prívalových deštư) je jejich funkce v některých obdobích kontraproduktivní. Proto jsou v současné době prijijimána opatření na drenážních systémech či v jejich návaznosti, která mohou zmírnit a eliminovat dopady obou hydrologických extrémů. Pro návrhy opatření, která stávající jednoúčelovou funkci odvodňovacích systémů rozširíi či jejich negativní efekty minimalizují (drenážní biofiltry, umělé mokřady a tůně na drenážních výustích, regulační drenáže), je však nutná znalost umístění dílčích prvků plošného odvodnění, především drenážních výustí. Informaci o umístění drenážní výusti Ize získat dohledáním, naskenováním a následnou orto-rektifikací podrobných situací staveb zemědělského odvodnění. Tento postup však není možné aplikovat vždy, protože $v$ období majetkových transformací v devadesátých letech 20. století byla značná část podkladů ztracena nebo zničena. Z těchto důvodů bylo testováno termografické snímkování jako nová metoda pro identifikaci drenážních výustí. Předpokladem pro její užití je skutečnost, že teplota drenážní vody a teplota vody v povrchovém toku jsou odlišné, zejména $\checkmark$ létě a v zimě. Termografickým snímkováním po délce vodního toku Ize identifikovat oblasti s náhlou změnou teploty, která identifikují místa prítoku vody do vodního toku. Na základě získaných výsledků Ize tvrdit, že termografie představuje užitečnou metodu k identifikaci drenážních výustí.

\section{ÚVOD}

Plocha provedených odvodnění dosahuje na celém světě podle dostupných zdrojů více než 200 milionů hektarů zemědělské půdy [1]. V České republice bylo odvodněno celkem 1016500 ha, což predstavuje více než $25 \%$ zemědělské půdy [2]. Drenážní systémy jsou v ČR obvykle koncipovány jako kombinace podrobného odvodňovacího zařízení (POZ), nejčastěji v podobě plošné podpovrchové trubkové drenáže (záchytné, sběrné a svodné drény), která je zaústěna do povrchových nebo zatrubněných hlavních odvodňovacích zařízení (HOZ) nebo prímo do drobných vodních toků (DVT). Odtok z drenážních systémů představuje zároveň $v$ podmínkách České republiky jeden z hlavních zdrojů podpovrchového plošného znečištění vod. Drenážním odtokem dochází zejména k vyplavování dusičnanů, některých pesticidů a jejich metabolitů i dalších látek rozpustných ve vodě. Množství látek vyplavované z půdy drenážními systémy je př́mo úměrné k velikosti a dynamice odtoku vody [3].

Drenážní systémy obecně urychlují odtok z povodí. Dynamika koncentrací většiny látek je v drenážních vodách velmi proměnlivá. Drenážní vody mohou mít pro jednotlivé složky odtoku značnou časovou variabilitu ve vazbě na průběh počasí, půdní a hydrogeologické podmínky povodí, nasycenost půdního profilu, dobu a intenzitu aplikace hnojiv, biochemické reakce v půdním prostředí, způsob využití území a jeho morfologii. Klíčový je tedy původ vody a cesty jejího odtoku do odvodňovacího systému [4-6].

Zabránit zhoršování stavu povrchových i podzemních vod a zlepšení jejich jakostního i kvantitativního stavu je cílem Rámcové směrnice Evropského parlamentu a Rady 2000/60/ES ze dne 23. řijna 2000, ustavující rámec pro činnost Společenství v oblasti vodní politiky. Plánování v oblasti vod je rozděleno do tř́ šestiletých období. Plošné zemědělské zdroje znečištění vod však v rámci předchozích dvou plánovacích období v oblasti vod nebyly analyzovány ani hodnoceny. Problematika hodnocení stavu vodních útvarů z hlediska vlivu plošných zemědělských zdrojů znečištění zůstala v procesu plánování v oblasti vod dosud téměř neřešena [7]. Třetí plánovací období probíhá od počátku roku 2016 do roku 2021 a realizace opatření tretího plánovacího období bude probíhat v letech 2022 až 2027. Pro efektivní návrhy opatření, které bude možné promítnout do třetího plánovacího období, musí být proto charakteristický multifunkční prínos. Navržená opatření musí nejen zajistit funkčnost staveb odvodnění zamokřených zemědělských pozemků, ale zároveň také vytváret zásoby vody pro letní období a tím snižovat rizika i dopady výskytu sucha agronomického, případně hydrologického [8]. Navržená opatření rovněž kromě aspektů optimalizace vodního režimu zemědělských pozemků, tj. eliminace hydrologických extrémů, musí přispět ke zlepšení samotné jakosti drenážních vod. Opatření musí být zaměřena především na snižení odnosu živin a dalších polutantů z povodí prostřednictvím zemědělského odvodnění [9-11].

Kvalita provedených návrhů opatření vychází z detailní znalosti řešeného území, jehož důležitou součástí je znalost umístění dílčích prvků plošného odvodnění, především drenážních výustí.

Odtok z drenáže se soustředuje prostřednictvím svodných drénů k drenážním výustím. V drenážních soustavách $v$ ČR se běžně vyskytují drenážní výusti v místech vyústění svodných drénů do odpadových př́kopů, kanálů či 
vodních toků [1]. Historicky znamenala realizace zvýšeného počtu drenážních výustí rovněž zvýšení stavebních nákladů. Z tohoto důvodu bylo drenážních vyústí realizováno co nejméně, a sice zpravidla jedna pro každou drenážní skupinu [1]. Mezi požadavky na konstrukční řešení drenážních výustí patří zajištění volného odtoku drenážní vody, odpovídající nákladovost, trvanlivost a jasné označení. Právě jasná identifikace $v$ terénu s ohledem na stárí realizovaných staveb odvodnění představuje zásadní problém pro návrhy opatření na drenážních systémech a samotných drenážních výustích. Dochované projektové dokumentace jednotlivých staveb zemědělského odvodnění vyžadují navazující pokročilé zpracování pro príbližnou lokalizaci drenážní výusti (navazujících prvků odvodnění). Jedná se především o nutné skenování dochovaných situací staveb odvodnění, jejich následnou rektifikaci a navazující digitalizaci. Výše popsané činnosti však často nevedou k úspěšné identifikaci drenážní výusti $\checkmark$ terénu (realizace stavby často nebyla prováděna $v$ souladu s projektovou dokumentací či drenážní výust' byla poškozena). Část situací staveb zemědělského odvodnění také není dochována. V tomto prípadě se nabízí jako jedna z možných metod identifikace drenážních výustí za pomoci termografického snímkování.

V současné době je v termografii aktuální zejména dílčí disciplína v podobě termografické diagnostiky, která měří charakteristiku vyzařování tepla za účelem zjištění výskytu poruchy, znečištění nebo nemoci. Jedná se o typ infračerveného zobrazování, které detekuje intenzitu tepelného záření v rozsahu elektromagnetického spektra pro vytvoření obrazu - termogramu [12]. Nástroje a poznatky z oboru termografie Ize využít jako alternativní prístup pro identifikaci drenážních výustí.

V zahraničí se již podobný výzkum uskutečnil, byl však zaměřen primárně na identifikaci potenciálních zdrojů znečištění. Př́íkladnými studiemi jsou např. [13-15], kde se autoři věnovali možnostem aplikace nových metod pro odhalování a vyhodnocování kontaminace pobřežních vod s využitím leteckých platforem termografie, řady pokročilých termovizních kamer a nového detekčního softwaru.

Hydrografická sít (vodní toky vč. hlavních odvodňovacích zařízení) je považována za hlavní proměnnou, která ovlivňuje rozmanitost (hydrologickou, biologickou či produkční - zemědělskou složku) v samotném vodním toku, ale i v celé navazující ploše povodí. V současnosti je jen málo známo o tepelné heterogenitě včetně jejích účincích na jakostní ukazatele vody či vodní biotu. Dynamikou a vlivem tepelného znečištění na vodní ekosystém se pomocí technik dálkového průzkumu Země príkladně zabýval ve své studii autor Tonolla a kol. [16]. Složení, uspořádání a stupeň hydrologické propojenosti těchto biotopů určuje stabilitu vodního prostředí a ekosystémové procesy [17, 18].

V oboru vodního hospodářství lze s využitím metod termografického snímkování diagnostikovat místa ve vodních tocích či nádržích se zvýšenou teplotou, která mohou mít negativní dopad na ekologickou stabilitu lokality [19], prípadně kompletně modelovat teplotní režim vodních toků [20]. Na základě rozdílné teploty mezi povrchovou a podpovrchovou vodou je také možná identifikace vyvěrajících pramenů vody [21]. Pramenné vývěry jsou potenciálně zaměnitelné za drenážní výusti a pro stanovení jakosti daného vývěru je zapotřebí laboratorní ověrení, jelikož nutně nepodléhá plošnému zemědělskému znečištění. Právě navazující oblastí využití termografie, tedy identifikací teplotních rozdílů mezi vodními toky (nádržemi) a drenážními vodami, se detailně zabývá představovaný výzkum. Cílem tohoto príspěvku je prezentovat dosažené poznatky z využití termografické metody pro identifikaci míst vtoku drenážních vod do recipientu (drenážních výustí) a zároveň představit zjištěné nesoulady mezi dochovanými situačními výkresy projektových dokumentací vybraných staveb zemědělského odvodnění a reálným stavem zjištěným z výsledků termografického snímkování.

\section{METODIKA}

V rámci predstaveného výzkumu bylo využito pozemní termografické měěení. Pomocí termovizní kamery byly snímkovány oblasti předpokládaných drenážních výustí do vodních toků, hlavních odvodňovacích zařizení či malých vodních nádrží. Na základě rozdílů $v$ teplotě vody byly identifikovány konkrétní polohy drenážních výustí. Konkrétní lokalizace drenážní výusti byla zaměřena a posléze porovnána s podklady z projektových dokumentací odvodňovací stavby.

Základní myšlenka, která stojí za tímto výzkumem, je rozšíriit možnosti využití termografického snímkování od detekce tepelného znečištění k detekci znečištění vod v obecném slova smyslu. Pro úspěšné využití termografie k detekci vstupu znečištění do povrchových vod musí být zároveň splněny dva předpoklady. Prvním předpokladem je, že teplota vody podpovrchového odtoku (drenážního) odtoku se bude lišit od teploty vody odtoku povrchového. Druhým předpokladem je, že se liší koncentrace látek v drenážním a povrchovém odtoku. Vzhledem ke skutečnosti, že teplota drenážní vody vykazuje menší rozdíly mezi letním a zimním období a na změnu teploty vzduchu reaguje se zpožděním oproti povrchovému odtoku [22] a zároveň koncentrace pro drenážní odtok charakteristických polutantů bývají v drenážních vodách vyšší než v povrchovém odtoku [6,9], termografické snímkování by mohlo umožnit identifikaci vtoku drenážních vod i znečištění drenážním odtokem vnášené. Dále by využití termografického snímkování mohlo poskytnout jednoduchou vizualizaci a popis jeho prostorového rozložení a přispět tak ke snazšímu určení př́čin znečištění, respektive lokalizovat místa pro návrh vhodných opatření.

\section{Př́strojové vybavení}

V rámci pozemního termografického měěení bylo testováno využití termografických kamer FLUKE - TiS20 (obr. 1) a FLIR řady E6 (obr. 2).

\section{TERMOGRAFICKÁ KAMERA FLUKE - TIS20 SE VYZNAČUJE NÁSLEDUJIICÍ ZÁKLADNÍ SPECIFIKACÍ

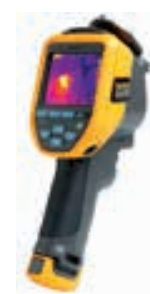 \\ - rozlišení $120 \times 90$ pixelu, \\ - obnovovací frekvence $9 \mathrm{~Hz}$, \\ - rozsah měření teploty $-20^{\circ} \mathrm{C}$ až $+350^{\circ} \mathrm{C}\left(-4^{\circ} \mathrm{F}\right.$ až $\left.662^{\circ} \mathrm{F}\right)$, \\ — prostorové rozlišení (IFOV) 5,2 $\mathrm{mRad}$ \\ - zorné pole $35,7^{\circ} \times 26,8^{\circ}$, \\ - rozměry $(V \times \breve{S} \times D): 26,7 \times 10,1 \times 14,5 \mathrm{~cm}$, \\ - hmotnost $720 \mathrm{~g}$.}

Obr. 1. Termografická kamera FLUKE - Tis20

Fig. 1. FLUKE - TiS20 Thermal Imaging Camera

Jedná se o základní termokameru pro měření rozložení teplot. Samotné získání dat probíhá zamírením na snímaný objekt a stisknutím „spouště“ pro pořízení termogramu. Kamera je vybavena funkcí prolínání IR-Fusion ${ }^{\oplus}$ - kdy jsou do samotného termogramu prolnuty hrany získané z optického snímku, což napomáhá snazší orientaci v pořízeném termogramu a identifikaci klíčových detailů. Termokamera disponuje displejem LCD 3,5“ 320 × 240, přičemž je doplněna o digitální fotoaparát s rozlišením $5 \mathrm{Mpx}$. 
TERMOGRAFICKÁ KAMERA FLIR E6 SE

VYZNAČUJE NÁSLEDUJIICÍ ZÁKLADNÍ SPECIFIKACÍ

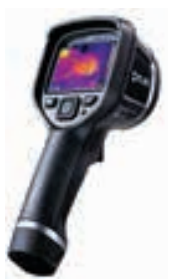

- rozlišení $160 \times 120$ pixelu,

- obnovovací frekvence $9 \mathrm{~Hz}$,

— rozsah měření teploty $-20^{\circ} \mathrm{C}$ až $+250^{\circ} \mathrm{C}\left(-4^{\circ} \mathrm{F}\right.$ až $\left.482^{\circ} \mathrm{F}\right)$,

— prostorové rozlišení (IFOV) 5,2 mRad,

- zorné pole $45^{\circ} \times 34^{\circ}$

— rozměry $(V \times \check{S} \times D): 24,4 \times 9,5 \times 14 \mathrm{~cm}$,

- hmotnost $575 \mathrm{~g}$.

Obr. 2. Termografická kamera FLIR E6

Fig. 2. FLIR E6 Thermal Imaging Camera

Termokamery FLIR řady Ex, tj. konkrétně termokamery FLIR E4, FLIR E5, FLIR E6, jsou určeny pro všeobecné použití ve stavebnictví i průmyslu. Jsou vhodné i pro termografickou analýzu povrchových vod a identifikaci drenážních výustí. Všechny termokamery této řady jsou plně kompatibilní se softwarem FLIR TOOLS a FLIRTOOLS+ s možností analýzy jednotlivých snímků. Součástí kamery je vestavěný digitální fotoaparát, který umožňuje pořízení fotografie zároveň s termogramem. Největši rozdíl mezi testovanými kamerami je, že termokamera FLIR E6 disponuje funkcí detekce hran snímaného objektu (IR-Fusion ${ }^{\circledR}$ ).

\section{Pilotní lokality a termografické kampaně}

Výzkum zaměřený na využití termografického snímkování pro potřeby identifikace drenážních výustí probíhal v letech 2018-2019. Jednalo se o jednu měřickou kampaň zaměřenou obecně na identifikaci bodových zdrojů znečištění a o další dvě měřické kampaně pozemního termografického snímkování, které byly speciálně zaměřené na identifikaci drenážních výustí. Dané kampaně probíhaly v termínech 17. 12. 2018 (lokalita Rokytky a Kunratického potoka) a 15. 1. 2019 (lokalita Dolského potoka v povodí Žejbra). Z důvodu špatného stavu projektové dokumentace a rozvíjející se zástavbě (zejména na hydrologicky souvisejícím území Prahy) bylo v rámci dvou kampaní provedeno ověření daného př́stupu celkem na pěti vybraných lokalitách (pěti vybraných stavbách zemědělského odvodnění). Vzhledem k výše uvedeným předpokladưm pro efektivní využití termografického snímkování za účelem identifikace drenážních výustí byly kampaně provedeny v zimním období, kdy je z dlouhodobých měření teplot drenážní vody patrné, že se její teplota v zimním období pohybuje okolo $5^{\circ} \mathrm{C}[22,23]$. Pro vyhodnocení termografických snímků drenážních výustí byla zvolena barevná paleta s názvem rainbow HC, jež je prezentována na obr. 3. Barevná stupnice rainbow HC byla zvolena především z důvodu vysoké citlivosti na změnu teploty.

Nejvyšší teploty jsou vždy prezentovány bílou barvou, nejnižší teploty barvou černou. Jednotlivé termogramy jsou vyhodnoceny automaticky, tedy nebyly sjednoceny na stejnou teplotní škálu. Z tohoto důvodu se u každého termogramu teploty liší, ačkoli mohou vypadat podobně.

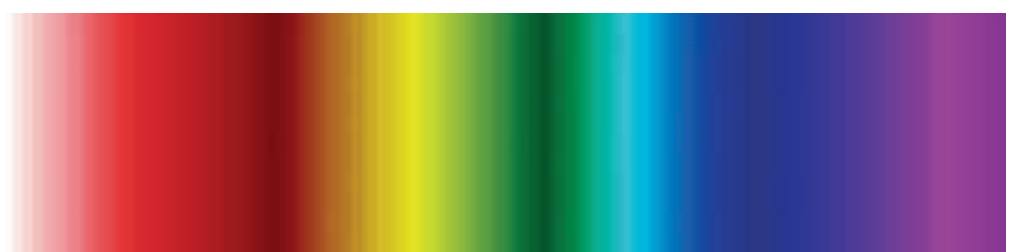

Obr. 3. Barevná škála rainbow HC

Fig. 3. Rainbow HC Thermal Palette

\section{Povodí Rakovnického potoka}

$\checkmark$ povodí Rakovnického potoka proběhlo dne 13. 12. 2018 termografické snímkování, které bylo vázáno primárně na identifikaci bodových zdrojů znečištění, především na bodové zdroje znečištění evidované v databázi správců Povodí (Povodí Vltavy, státní podnik) - objekty vypouštění. Hlavní poznatky z termografické kampaně byly prezentovány v článku Marvala a kol. [24]. V rámci této kampaně byla identifikována v povodí Hájevského potoka (obr. 4) v lokalitě Kněževes, kromě definovaného objektu vypouštění (čistírna odpadních vod), rovněž drenážní výust'. Daná drenážní výust' (obr. 5) nebyla na první pohled patrná a její identifikace a lokalizace proběhla pouze díky využití termografické kamery. Povodí Hájevského potoka $(22,8$ km²) se nachází na severozápadním okraji Středočeského kraje. Jedná se o intenzivně zemědělsky využívané povodí, přičemž standardní orná půda zabírá 70,6 \% území a chmelnice se rozléhají na $12,8 \%$ plochy povodí. Odvodněná plocha se podle vrstvy bývalé Zemědělské vodohospodářské správy (ZVHS) rozléhá na cca 2,5 km², což činí 11,0\% celkové plochy povodí. Nalezená drenážní výusț byla identifikována náhodně, aniž by předem bylo ž̌ejmé, že se na daném území drenážní stavba nachází. Vrstva odvodnění podle bývalé ZVHS takovouto stavbu nereflektuje, což je zřejmé z obr. 4. Stejně tak není zachován prováděcí výkres stavby odvodnění ve spisové a archivní dokumentaci bývalých pracovišt ZVHS, která se nachází ve spisovně Povodí Vltavy, s. p., na vodním díle Orlík.

Získaný poznatek vyvolal potřebu navazujících měřických kampaní, které již byly primárně zaměřeny na možnou identifikaci drenážních výustí pomocí termografického snímkování. S přihlédnutím k nejistotě dosažených poznatků a možnostem využití termokamery v oboru vodního hospodářství byla první kampaň provedena zapůjčenou termokamerou FLUKE - TiS20. V návaznosti na nově získané poznatky v první termografické kampani byl pro druhou a třetí kampaň zajištěn obdobný model termokamery (FLIR E6).

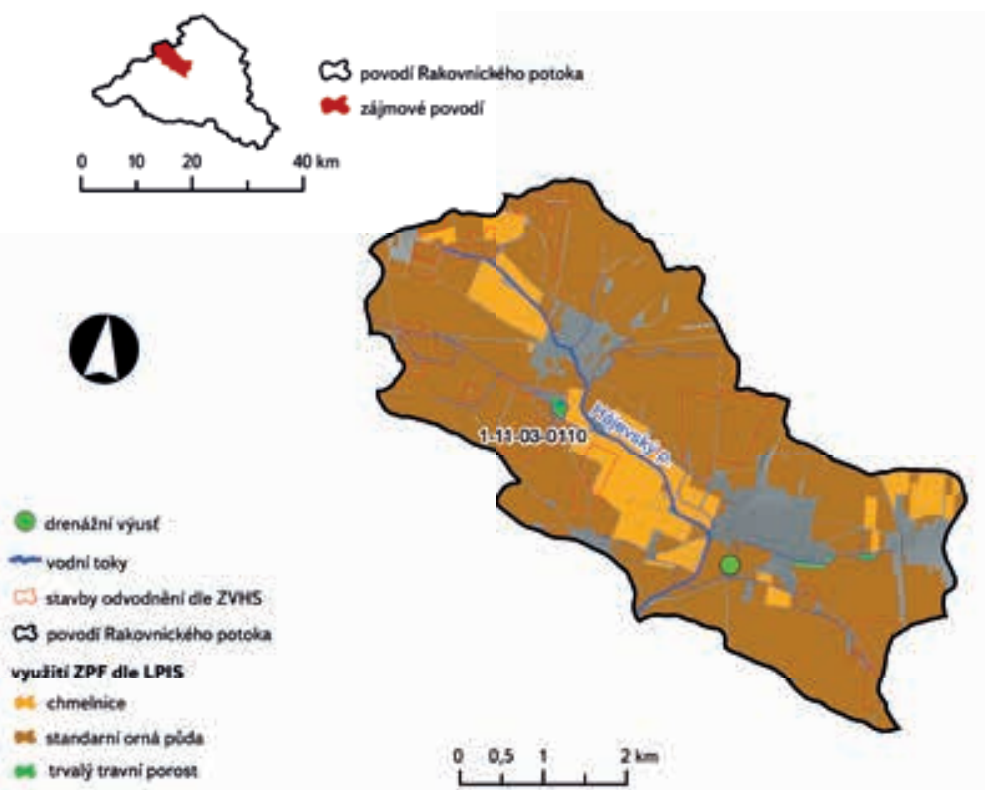

Obr. 4. Pilotní lokalita - povodí Hájevského potoka

Fig. 4. The pilot location - the Hájevský stream catchment 


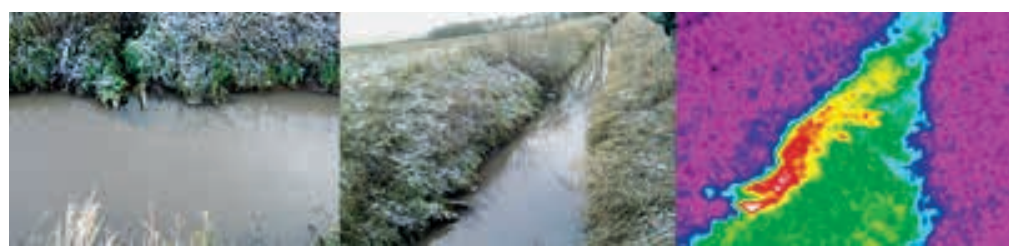

Obr. 5. Identifikovaná drenážní výust' (DV1) v povodí Hájevského potoka Fig. 5. The identified drainage outlet in the Hájevský stream catchment

\section{Povodí Kunratického potoka a Rokytky}

Pro ověření možnosti identifikace drenážních výustí termografickou kamerou byly na základě dostupnosti podkladů ke stavbám odvodnění (data odvodnění - ZVHS, projektové dokumentace a situace staveb zemědělského odvodnění) vybrány další lokality, kde byly provedeny částečné termografické kampaně. Mimo povodí Hájevského potoka byly částečně monitorovány další lokality plošného zemědělského odvodnění na vybraných povodích IV. rádu. Jednou z nich byla povodí v hydrologicky souvisejícím území Prahy. Konkrétně se jednalo o povodí Kunratického potoka (ČHP 1-12-01-006) a horní povodí Rokytky k Běchovicím (ČHP 1-12-01-026).

Pro hydrologicky související území Prahy, tj. území, ze kterého přitéká povrchová voda na území Prahy (vyjma povodí Vltavy a Berounky), jsou v současnosti digitalizována data o plošném zemědělském odvodnění. Tato aktivita probíhá v rámci projektu s názvem „Nástroje pro efektivní a bezpečné hospodaření se srážkovou vodou na území Prahy - RainPRAGUE" podpořeným Operačním programem - Praha pól růstu. Na podkladě poskytnutých prováděcích situačních výkresů staveb zemědělského odvodnění od spisovny Povodí Vltavy, s. p., pro hydrologicky související území Prahy byly vytipovány drenážní výusti pro navazující ověření v terénu. Na předem určených místech poté probíhalo ověření možnosti identifikace drenážních výustí pomocí termografického snímkování. Bližší specifikace pilotních lokalit v okolí hl. m. Prahy je uvedena na obr. 6.

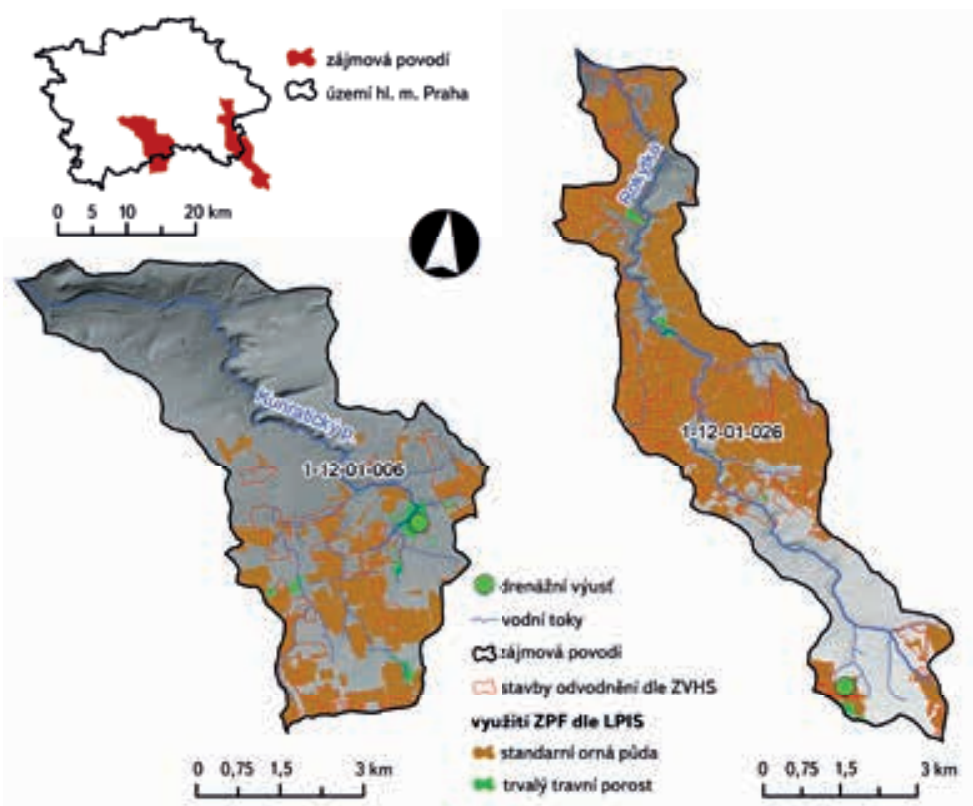

Obr. 6. Pilotní lokality - povodí Kunratického potoka a horní část povodí vodního toku Rokytky

Fig. 6. The pilot location - the Kunratický stream catchment and the upper part of the Rokytka catchment

\section{Povodí Žejbro}

Třetí lokalitou pro ověření možnosti identifikace drenážních výustí byla vybrána dvě povodí IV. rádu v povodí vodního toku Žejbra. Jedná se o dlouhodobě sledovanou lokalitu Výzkumného ústavu meliorací a ochrany půd, v. v. i., (VÚMOP) pro řešení problematiky plošného zemědělského odvodnění. Na této lokalitě má VÚMOP zajištěné a ortorektifikované prováděcí výkresy staveb zemědělského odvodnění, na jejichž základě byly $v$ minulosti identifikované drenážní výusti. $V$ rámci provedené termografické kampaně byly tyto výusti využité pro ověření jejich identifikace pomocí termografického snímkování. Lokality v povodí vodního toku Žejbro jsou blíže specifikovány na obr. 7.

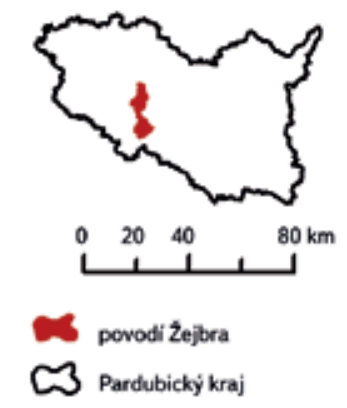

drenẩni víust

$\sim$ vodni toky

C3 powodi IV, rádu

C3 stavby odvodnèní dle ZVHS

využiti ZPF dle LPIS

$\checkmark$ standarni orná pùda

trvaly travni porost
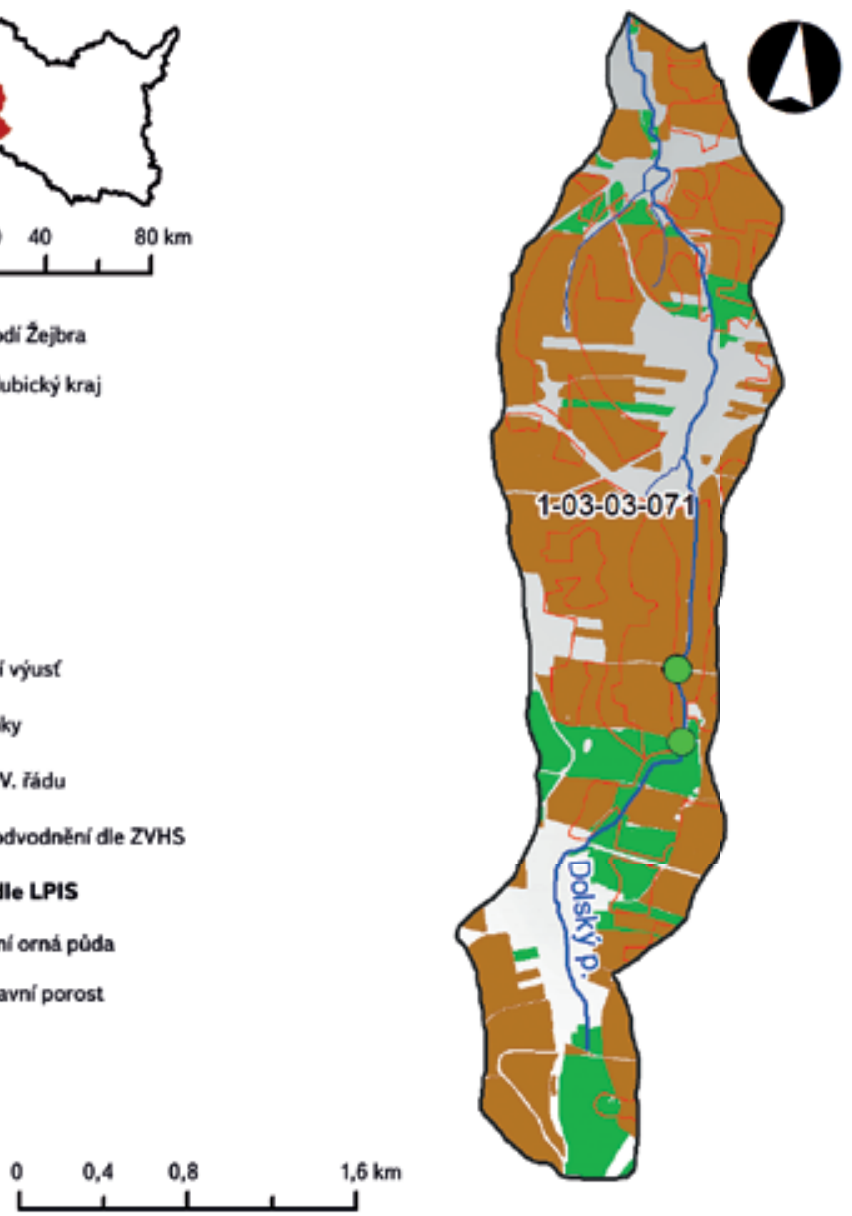

Obr. 7. Pilotní lokality - povodí Dolského potoka

Fig. 7. The pilot location - the Hájevský stream catchment

\section{VÝSLEDKY}

Dosažené výsledky jsou prezentovány formou rektifikovaného situačního výkresu stavby odvodnění v kombinaci s pořízenými termogramy doplněné o RGB snímky. Teploty vody a její rozdíly $v$ jednotlivých měřených lokalitách $\checkmark$ místech drenážních výustí a nad prítokem drenážní vody jsou prezentovány prostřednictvím tabulky 1 , kde jsou uvedeny konkrétní teploty zajištěné prostřednictvím ručního referenčního měření. 
Tabulka 1. Teplota na měrených drenážních výustích a recipientu (prítok/nad prítokem)

Table 1. Temperatures of the drainage outlet and the recipient

\begin{tabular}{|c|c|c|c|c|c|c|c|}
\hline Povodí & ČHP povodí & Datum & Označení & Recipient & $\begin{array}{l}\text { Teplota } \\
\text { recipientu }\left[{ }^{\circ} \mathrm{C}\right]\end{array}$ & $\begin{array}{l}\text { Teplota } \\
\text { přítoku }\left[{ }^{\circ} \mathrm{C}\right]\end{array}$ & $\begin{array}{l}\text { Rozdíl } \\
\text { teplot }\left[{ }^{\circ} \mathrm{C}\right]\end{array}$ \\
\hline Hájevského potoka & $1-11-03-0110$ & $12 / 13 / 2018$ & DV1 & $\mathrm{HOZ}$ & 3,1 & 7,6 & 4,5 \\
\hline Kunratického potoka & $1-12-01-006$ & $12 / 17 / 2018$ & DV2 & rybník Jordán (Nový Šeberov) & 0,0 & 5,7 & 5,7 \\
\hline Rokytky & $1-12-01-026$ & $12 / 17 / 2018$ & DV3 & $\mathrm{HOZ}$ & 7,0 & 3,1 & 3,9 \\
\hline Dolského potoka & $1-03-03-071$ & $1 / 15 / 2019$ & DV4 & Dolský potok & 2,0 & 6,3 & 4,3 \\
\hline Dolského potoka & $1-03-03-072$ & 1/15/2019 & DV5 & Dolský potok & 1,5 & 6,3 & 4,8 \\
\hline Dolského potoka & $1-03-03-072$ & 1/15/2019 & DV6 & Dolský potok & 1,5 & 7,6 & 6,1 \\
\hline
\end{tabular}

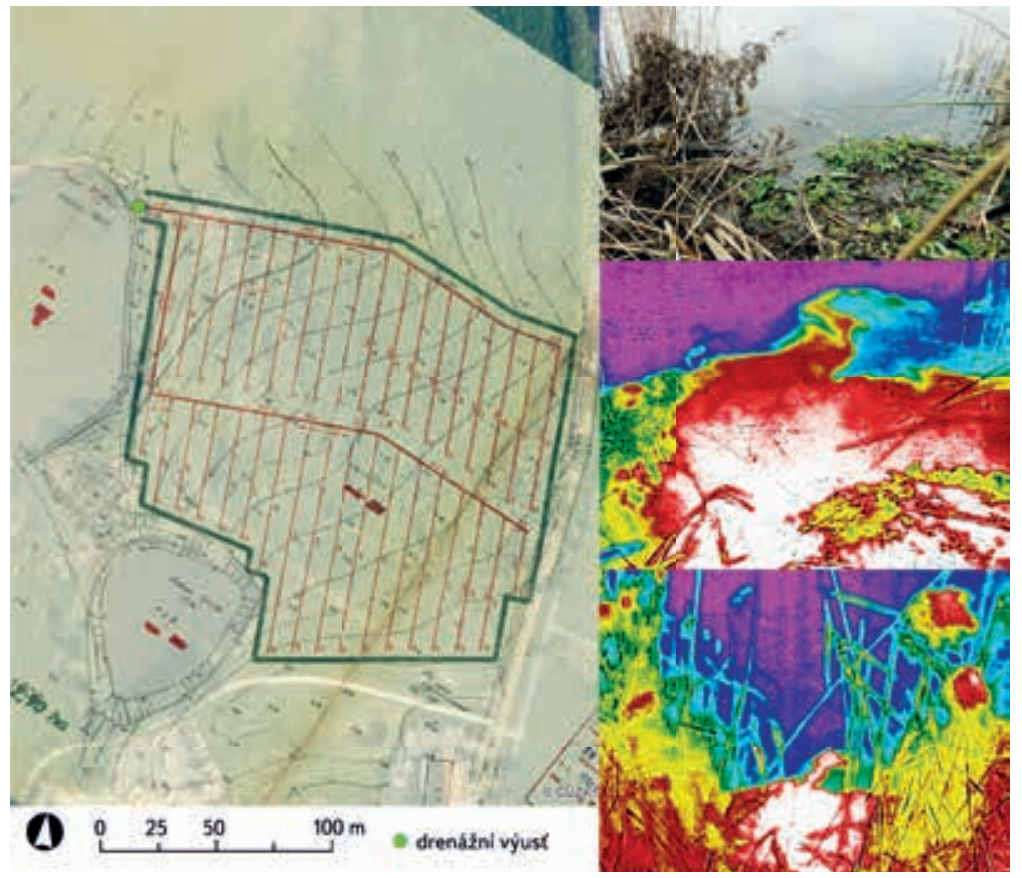

Obr. 8. Rektifikovaná stavba odvodnění, termogramy teplotního rozložení v místě drenážní výustě a recipientu (rybník Nový Šeberov) a fotodokumentace - povodí Kunratického potoka

Fig. 8. The rectified drainage system, thermograms showing temperature distribution at the drainage outlet and recipient (Nový Šeberov pond) and photo documentation the Kunratický stream catchment

Na obr. 8 je prezentována identifikovaná drenážní výust' (DV2) v pilotní lokalitě Kunratického potoka. Termogramy demonstrují teplotní rozložení vody v místě drenážní výustě a vodní hladiny rybníku Nový Šeberov. Vodní hladina byla pokryta slabou vrstvou ledu a drenážní voda dosahovala teploty $5,7^{\circ} \mathrm{C}$. Za pomoci vysokého teplotního rozdílu a vodnosti stavby odvodnění bylo možné danou výust' identifikovat. Daná stavba odvodnění (obr. 8) má rozlohu 2,8 ha a celý drenážní odtok je soustředěn do jediné identifikované drenážní výusti. Přestože byla stavba odvodnění vybudována již v roce 1977, je stále funkční. To se pravděpodobně v blízké budoucnosti změní vzhledem k faktu, že je plocha stavby zemědělského odvodnění aktuálně z 60 \% zalesněná. Lze předpokládat, že kořenový systém, $v$ současnosti mladého lesa, $v$ brzké budoucnosti funkci drenážní stavby významně omezí. První náznaky lokálního zamokření, které vzniká v místech porušení drénů, jsou již patrné ze satelitních snímků.
V případě pozvolného vtoku vody o vyšší teplotě (drenážní vody) do stojaté vody, jak je prezentováno na obr. 8, dochází k relativně pomalému šírení tepla prouděním neboli konvekcí. Jedná se o jev, kdy dochází ke vzájemnému pohybu jednotlivých částí, které mají odlišnou teplotu a tedy různou hustotu vnitřní energie, tím se přenáší teplo, prostřednictvím čehož se drenážní voda postupně ochlazuje. V zemské atmosféře obvykle hustota kapalin nebo plynů klesá s narůstající teplotou. V gravitačním poli tedy ohřáté vrstvy kapaliny nebo plynu stoupají, zatímco ty chladnější klesají ke dnu. Fakt, že šíření tepla po vodní hladině není ovlivněno turbulentním prouděním, zvyšuje účinnost možné identifikace drenážní výusti s využitím termografického snímkování. To je dáno velikostí oblasti s vodou o vyšší teplotě, což souvisí s prodlouženou dobou, po kterou drenážní voda zůstává na hladině, a proti vtoku do vodního toku není ovlivněna turbulentním prouděním. To však podmiňuje vodnost drenážní výusti, kdy se zvětšujícím se prưtokem roste i tepelně znečištěná plocha.

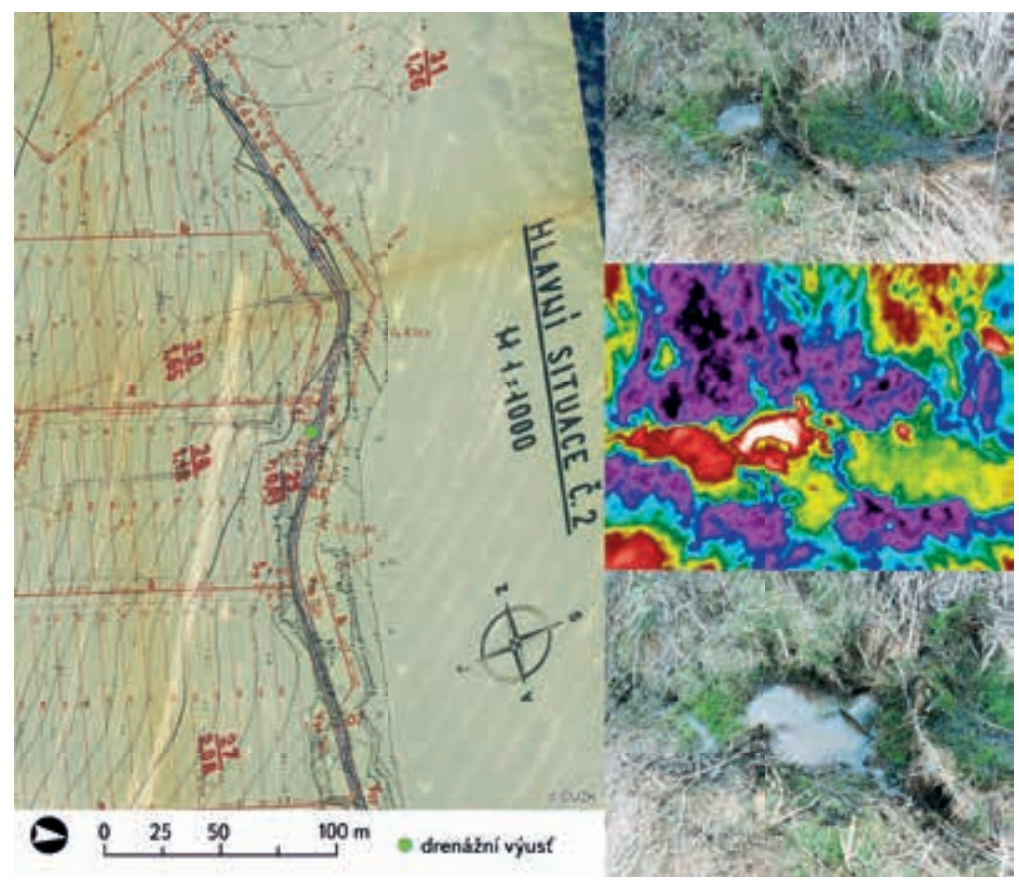

Obr. 9. Rektifikovaná stavba odvodnění, termogram drenážní výusti a fotodokumentace před a po provedené identifikaci v povodí Rokytky

Fig. 9. The rectified drainage structure, a thermogram of the drainage outlet and photo documentation from before and after the identification in the Rokytka catchment 
Další drenážní výust' (DV3) identifikovaná pomocí termografického snímkování se nachází v povodí vodního toku Rokytky. V době termografické kampaně byla vodnost hlavního odvodňovacího zařízení (HOZ) minimální, přesto byla podniknuta rekognoskace celé lokality. Identifikovaná výust’ se nachází cca $13 \mathrm{~m}$ od předpokládané polohy podle rektifikovaného prováděcího výkresu, viz obr. 9. Při pochůzce podél HOZ byla detekována teplá oblast, viz termogram na obr. 9. Stav před a po identifikaci je možné porovnat v přiložené fotodokumentaci. Na první pohled drenážní výust není patrná a až po odkrytí cca $5 \mathrm{~cm}$ silné vrstvy pokryvu bylo možné výust spatřit. Průtok drenážní výusti byl velm nízký, avšak pro identifikaci pomocí termografického snímkování dostatečný i vzhledem k promrzlému okolí výusti. Identifikovaná drenážní výust̉ odvádí vodu z plochy 1,9 ha.

V dokumentaci bývalé ZVHS je uvedeno, že stavba odvodnění byla budována v roce 1970, je však pravděpodobné, že došlo k její částečné obnově vzhledem k materiálu, ze kterého je drenážní výust vyrobena (tvrzený plast). Podle prováděcího výkresu stavby zemědělského odvodnění jsou zaústěny do HOZ další čtyři svodné drény, ovšem při terénní rekognoskaci se podařilo identifikovat pouze jedinou výust' na této lokalitě. To bylo zapříčiněno z důvodu nízké vodnosti nebo nefunkčnosti dalších částí odvodňovací stavby.

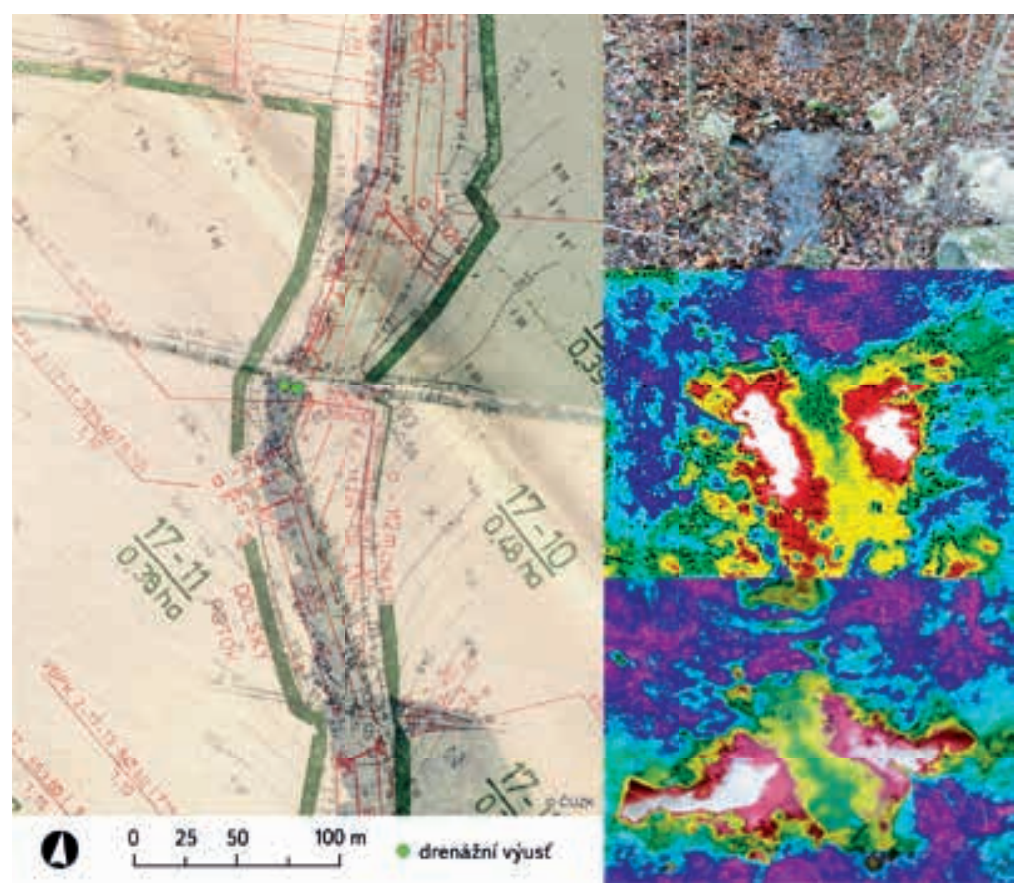

Obr. 10. Rektifikovaná stavba odvodnění, termogramy drenážních výustí a fotodokumentace $v$ povodí Dolského potoka

Fig. 10. The rectified drainage structure, thermograms of the drainage outlets and

photo documentation from the Dolský stream catchment

Na obr. 10 jsou prezentovány dvě drenážní výusti (DV4 a DV5), identifikované termografickým snímkováním v povodí Žejbro. Na rektifikovaném situačním výkresu jsou zakreslené výusti na obou stranách Dolského potoka. Na pravém břehu se reálná poloha výusti liší proti prováděcímu výkresu přibližně o $8 \mathrm{~m}$ a na levém břehu je rozdíl $50 \mathrm{~m}$. Reálné polohy výustí jsou oproti prováděcí dokumentaci posunuty severním směrem. Dále byly ze situačního výkresu odečteny plochy, odkud daná výust' odvádí vodu. Na pravém břehu se jedná o plochu cca 0,48 ha, na levém 0,38 ha. Vzhledem k minimálním atmosférickým srážkám před provedením termografické kampaně byla funkčnost plošného zemědělského odvodnění z malých rozloh překvapující a je pravděpodobné, že situační výkres plošného zemědělského odvodnění neodpovídá skutečnosti a identifikované výusti reálně odvádějí vodu z rozsáhlejších odvodněných ploch. V pravé části obr. 10 je uvedena fotografie drenážních výustí, termogram zachycující tepelné šiření proti proudu Dolského potoka a kombinace fotografie s částečně zprůhledněným termogramem tepelného šírení po proudu Dolského potoka. Teplotní rozdíl drenážních vod a recipientu dosahoval $4,8^{\circ} \mathrm{C}$, respektive $6,1^{\circ} \mathrm{C}$. Splněnými podmínkami (vodnost drenážních výustí a vysoký teplotní rozdíl) byla opětovně potvrzena využitelnost termografického snímkování za účelem identifikace drenážních výustí, tedy potenciálního znečištění povrchových vod ze zemědělského pozemku.

$\checkmark$ daném povodí byla identifikována také třetí výust' (DV6). Jedná se o výust', která se nachází přibližně o 350 m výše proti proudu Dolského potoka od DV4 a DV5. Předmětná drenážní výust' odvádí vodu z plochy 6,16 ha, přičemž její vodnost byla srovnatelná s předešlými dvěma výustěmi v povodí Dolského potoka, u kterých je sběrná plocha podle dostupné dokumentace cca dvanáctkrát menší. Mimo této identifikované výusti by se $v$ blízkém okolí podle dokumentace mělo nacházet dalších pět drenážních výustí, avšak jejich skutečnou polohu nebylo možné ověrit využitím termografického snímkování z důvodu nulového průtoku v průběhu prováděné kampaně.

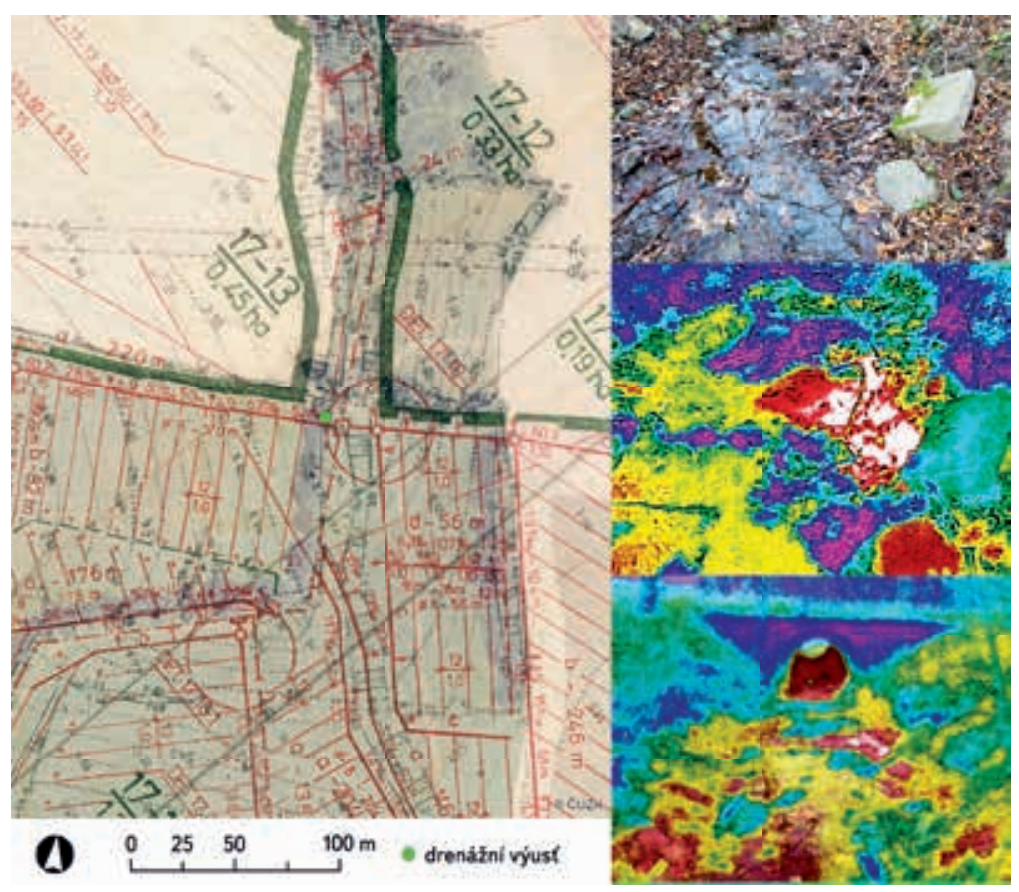

Obr. 11. Rektifikovaná stavba odvodnění, termogramy drenážních výustí a fotodokumentace v povodí Dolského potoka

Fig. 11. The rectified drainage structure, thermograms of the drainage outlets and photo documentation from the Dolský stream catchment

\section{DISKUSE}

Podpovrchové zdroje znečištění jsou v podmínkách ČR zastoupeny zejména plošným zemědělským odvodněním, které způsobuje mj. zvýšené vyplavování rozpuštěných látek (dusičnany a některé pesticidy). Vnos všech těchto polutantů do vod úzce souvisí s dynamikou počasí (zvyšující se nepravidelnost srážek, dlouhá období sucha, př́ivalové srážky) a nízkou retencí vody v povodí [25]. Pro návrhy prírodě blízkých a technických opatření na zemědělské půdě (stavbách zemědělského odvodnění), které prrispějí k eliminaci podpovrchových zdrojů znečištění, je nutná znalost prostorového rozmístění jednotlivých prvků staveb odvodnění. Pro návrh konkrétního opatření na zemědělském pozemku je proto znalost umístění odvodňovací stavby v terénu rozhodující. Odvodnění zemědělské půdy bylo provedeno z $98 \%$ plošnou, tj. systematickou trubkovou 
drenáží. Přes značnou snahu archivovat a v dobrém stavu uchovávat projektové dokumentace ke stavbám odvodnění, je nutné konstatovat, že evidence provedených staveb odvodnění (zejména podpovrchových) není kompletní [26].

Chybějící datové podklady (či dochované s určitou mírou nepřesnosti) je proto nutné zrevidovat, aby bylo možné pracovat s podklady, které odpovídají samotné realizaci stavby plošného zemědělského odvodnění v terénu. $\checkmark$ současnosti neexistuje ucelený celostátní informační systém o realizovaných stavbách odvodnění. Jediným dostupným podkladem v digitální podobě je volně dostupná geoinformační vrstva odvodněných ploch ve vektorovém formátu shapefile (.shp). Uvedený datový podklad představuje historicky pořízený datový zdroj bývalé Zemědělské vodohospodářské správy, který vznikl digitalizací původních analogových map s plochami realizovaných staveb zemědělského odvodnění [26]. Geometrický i atributový rozsah dat této informační vrstvy je však nekompletní a často i lokalizačně nepřesný, přičemž informace o realizovaných výustích drenážních systémů prakticky zcela chybí.

Alternativou pro určení základního identifikačního prvku př́tomnosti stavby odvodnění v samotném terénu, v podobě drenážní výusti, se tak nabízí prezentovaný způsob identifikace pomocí využití nástrojů termografického snímkování.

Prezentované dílčí výsledky shrnují závěry získané z prvotních dvou kampaní termografického snímkování zaměřeného na identifikaci drenážních výustí. Provedené kampaně byly uskutečněny jako referenční měřicí akce prostřednictvím ruční termokamery FLUKE - TiS20/FLIR E6. Daný způsob potvrdil potenciál vědního oboru termografie k identifikaci konkrétní polohy drenážní výusti v terénu.

Pro úspěšnou identifikaci drenážních výustí pomocí termografie musí být splněny následující predpoklady:

- vodnost př́toku (drenážní výusti) a recipientu (vodní

tok, hlavní odvodňovací zařizení, vodní nádrž),

— teplotní rozdíl minimálně $3^{\circ} \mathrm{C}$.

Proto se jako ideální období pro provedení daných kampaní jeví začátek zimy, kdy recipient není zamrzlý, avšak jeho teploty klesají k $0{ }^{\circ} \mathrm{C}$ a drenážní voda si drží teplotu přibližně v rozmezí $4-8^{\circ} \mathrm{C}[22,23]$. Další podmínkou úspěšné identifikace drenážních výustí je vodnost jak prítoku, tak i recipientu. S tím je v posledních letech v podmínkách ČR poměrně značný problém. Především tato podmínka omezuje daný prístup aplikovat v širokém měřítku. Dalším problémem je samotný stav staveb zemědělského odvodnění, kdy poměrně velké procento pravděpodobně není funkční.

Širší aplikovatelnost termografického snímkování pro identifikaci drenážních výustí je možné spatřovat především ve využití leteckého termografického snímkování. Letecká termografie má bezesporu značný potenciál. V současné době tato technologie zažívá nebývalý rozvoj a je možné tedy očekávat nové cesty vývoje leteckých termovizních kamer a jejich rozlišení i s ohledem na vývoj bezpilotních letounů a možnosti družicového snímkování. Letecké řešení sběru dat má výraznou výhodu při vyhledávání teplotních změn v místech, kde není jisté, že se tyto jevy vyskytují. To je umožněno především rychlým získáváním dat na velké ploše a širokým úhlem záběru (žádná hluchá místa, kde by mohly být neznámé teplotní změny) [12].

Naopak využití pozemního řešení sběru dat, at’ už dynamickým, či statickým způsobem přináší výraznou flexibilitu a operativnost. Limitujícím faktorem plošného sběru dat pozemním měřením je však jeho časová náročnost. Proto se do budoucna jako ideální řešení jeví kombinace obou těchto řešení $\checkmark$ podobě rychlého plošného sběru dat s využitím leteckého řešení, zpřesněný o data následného doměření pozemní metodou v konkrétních vybraných lokalitách.

\section{ZÁVĚR}

Sběr termografických dat je jedním z řady nových způsobů získávání dat o vodních ekosystémech (identifikace znečištění či právě drenážních výustí). Samotné termografické snímkování pozemní i letecké je dynamicky se rozvíjející obor, který v oblasti vodního hospodářství nabízí efektivní nástroj pro preventivní diagnostiku z pohledu identifikace zdroje znečištění vod [12, 24]. Tepelné znečištění ze stacionárních zdrojů podél vodních toků a ploch je samo o sobě závažným problémem s významnými ekologickými důsledky pro místní ekosystémy. Identifikace zdrojů tepelného znečištění a kvantifikace jejich vlivu je tak důležitým prvním krokem pro ochranu těchto ekosystémů. Zároveň je určení místa vtoku teplotně odlišné vody prvotním indikátorem pro lokalizaci potenciálního zdroje znečištění z pohledu zvýšených koncentrací vnášených polutantů.

$\checkmark$ příspěvku byla pozornost soustreděna na samotnou identifikaci teplotně odlišného vodního zdroje vstupujícího do hlavního vodního toku (hlavního odvodňovacího zařízení) v podobě prítoku z drenážních výustí. Současně běžně dostupné datové podklady neumožňuji konkrétní určení místa drenážních výustí. Toto se stává limitujícím faktorem při návrzích opatření směřujících k omezení podpovrchových zdrojů znečištění.

Způsob identifikace drenážních výustí pomocí termografického měření prokázal dobré možnosti uplatnění. Jeho širši využití je vázáno především na leteckou termografii, zejména na autonomní bezpilotní letouny. Předem nadefinované trajektorie letu nad hlavními odvodňovacími zařízeními/vodními toky v povodích s plošným podpovrchovým odvodněním v kombinaci s kontinuálním sběrem termografických dat předurčuje danou metodu k širokému uplatnění v komerční i státní sféře.

\section{Poděkování}

Tento príspěvek vznikl za podpory Technologické agentury ČR, projektu číslo TH02030396 "Využití letecké termografie jako nového prístupu pro identifikaci znecištěni vod z bodových a nebodových zdrojü" a za podpory Evropské unie v rámci Operačního programu Praha - pól růstu ČR, číslo projektu CZ.07.1.02/0.0/0.0/17_049/ 0000842, "Nástroje pro efektivní a bezpečné hospodaření se srážkovou vodou na území Prahy - RainPRAGUE".

\section{Literatura}

[1] JU゚VA, K. Odvodňování půdy. Praha, 1957, 526 s.

[2] KULHAVÝ, Z., DOLEŽAL, F, FUČIKK, P., KULHAVÝ, F., KVIITEK, T., MUZIKÁR̆, R., SOUKUP, M., and ŠVIHLA, V. Management of agricultural drainage systems in the Czech Republic. Irrigation and Drainage, USA 2007, 56, p. 141-149. ISSN 1531-0353.

[3] NOVÁK, P. FUČIK, P, KULHAVÝ Z a kol Príprava listů opatření typu A lokalit plošného zemědëlského znečištěni pro plány díľčch povodí Metodický návod - identifkace kritických bodiu a kategorizace lokali ohrožených znečišténím z pourchových a podpourchových plošných zemëdëlských zdrojü pro celé úzzem České republiky v podrobnosti sloužíci k tvorbě listư opatřeni typu A. Certifikovaná metodika. VúMOP. v. v. i., 2016, 69 s.

[4] ZAJǏ́EKE, A., KAPLICKÁ, M., FUČÍK, P., PETERKOVÁ, J., DUFFKOVÁ, R. a MAXOVÁ, J. Vyhodnocen podili̊ sráǩko-odtokových epizod na celkovém odnosu dusíku a fosforu z odvodněné zemědělské pưdy. Vodní hospodárství, 2017, č. 10, roč. 67, s. 1-6. ISSN 1211-0760.

[5] ZAJÍČEK, A., FUČĆK, P., KAPLICKÁ, M. a MAXOVÁ, J. Vyplavování pesticidních látek zemědělskou drenáží. Rostlinolékař, 2017, 4, s. 24-28. ISSN 1211-3565.

[6] ZAJÍČEK, A., FUČÍK, P., KAPLICKÁ, M., LIŠKA, M., MAXOVÁ, J., and DOBIÁŠ, J. Pesticide leaching by agricultural drainage in sloping, mid-textured soil conditions - the role of runoff components. Water Science and Technology, 2018, 77 (7-8), p. 1879-1890. ISSN 0273-1223. DOI: 10.2166/wst.2018.068.

[7] KVÍTEK, T. a KRÁTKÝ, M. Listy opatření typu A v Plánech dílčích povodí Vltavy - opatření ke zlepšení retence a kumulace vody v krajině společně s ochranou jakosti povrchových a podzemních vod. In: Rožnovský, J., Litschmann, T. (eds): Hospodařeni s vodou v krajině. Třeboň 21.-22. 6. 2018. ISBN 978-80-87361-83-2 
[8] KULHAVÝ, Z., ČMELÍK, M., ŠTIBINGER, J. a ŠRIPKO, J. Rekonstrukce staveb odvodněnís uplatněním principu regulace drenážního odtoku. Certifikovaná metodika, 2015. ISBN 978-80-87361-47-4

[9] FUČIK , P., BYSTŘ̈ICKÝ, V., DOLEŽAL, F., LECHNER, P., KVIITEK, T., VÁCHAL, J. a ŽLÁBEK, P. Posuzování vlivu odvodňovacích systémů a ochranných opatření na jakost vody v zemědělsky obhospodařovaných povodích drobných vodních toků. Metodika, 2010. VúMOP, v. v. i., 90 s. ISBN 978-80-87361-00-9.

[10] DUFFKOVÁ, R., ZAJÍČEK, A. a FUČíK, P. Vyplavení dusíku a fosforu z malých zemědělských odvodněných povodís aplikací různých hnojiv. Vodní Hospodářství, 2014, č. 12, s. 1-5. ISSN 1211-0760.

[11] DOLEŽAL, F. and KVITTEK, T. The role of recharge zones, discharge zones, springs and tile drainage systems in peneplains of Central European highlands with regard to water quality generation processes. Phys. Chem. Earth., 2004, 29, p. 775-785. DOI:10.1016/j.pce.2004.05.005.

[12] MARVAL, Š., HEJDUK, T., ROUB, R., VYBÍRAL, T., KAPLICKÁ, M. a BUREŠ, L. Využití letecké termografie jako nového prístupu pro identifikaci znečištění vod z bodových a nebodových zdrojů. Vodn hospodárství, 2018, č. 9, roč. 68, s. 8-13. ISSN 1211-0760.

[13] LEGA, M. and NAPOLI, R.M.A. Aerial infrared thermography in the surface waters contamination monitoring. Desalination and Water Treatment, 2010, 23, 1-3, p. 141-151.

[14] LEGA, M. KOSMATKA, J., FERRARA, C, RUSSO, F, NAPOLI, R.M.A. and PERSECHINO, G, Using Advanced Aerial Platforms and Infrared Thermography to Track Environmental Contamination. Environmental Forensics, 2012, 13, 4, p. 332-338

[15] LEGA, M., FERRARA, C., PERSECHINO, G., and BISHOP, P. Remote sensing in environmental police investigations: aerial platforms and an innovative application of thermography to detect several illegal activities. Springer International Publishing Switzerland, 2014.

[16] TONOLLA, D., WOLTER, C., RUHTZ, T., and TOCKNER, K. Linking fish assemblages and spatiotemporal thermal heterogeneity in a river-floodplain landscape using high-resolution airborne thermal infrared remote sensing and in-situ measurements. Remote Sensing of Environment, 2012, 125, p. 134-146.

[17] TOCKNER, K. and STANFORD, J.A. Riverine floodplains: Present state and future trends. Environmental Conservation, 2002, 29, p. 308-330.

[18] WARD, J.V. Riverine landscapes: Biodiversity patterns, disturbance regimes, and aquatic conservation. Biological Conservation, 1998, 83, p. 269-278.

[19] ŠIMKO, M. a CHUPÁČ, M. Aplikačnémožnostitermovízievpraxi. FCC Public 2006, [online: cit.16-02-2017] Dostupné z: http://www.odbornecasopisy.cz/elektro/casopis/tema/aplikacne-moznosti-termovizie-v-praxi--13327

[20] STEEL, E.A., BEECHIE, T.J., TORGERSEN, CH.E., and FULLERTON, A.H. Envisioning, Quantifying, and Managing Thermal Regimes on River Networks. BioScience [online], 2017, Vol. 67, No. 6, p. 506-522 [cit. 2018-10-22]. DOI: 10.1093/biosci/bix047. ISSN 0006-3568. Dostupné z: https://academic.oup.com/ bioscience/article-lookup/doi/10.1093/biosci/bix047

[21] SCHUETY, T. and WEILER, M. Quantification of localized groundwater inflow into streams using ground-based infrared thermography. Geophysical research letters, 2011, Vol. 38.

[22] ZAJIČEK, A. KVITEK, T. KAPLICKÁ, M., DOLEŽAL, F, KULHAVÝ, Z, BYSTŘICKÝ, V., and ŽLÁBEK, $P$. Drainage water temperature as a basis for verifying drainage runoff composition on slopes. Hydrological Processes, 2011, No. 20, Vol. 25, p. 3204-3215. DOl: 10.1002/hyp.8039.

[23] ZAJÍČEK, A., ŠANDA, M., TACHECÍ, P. a KVÍTEK, T. Doba zdržení vody v systému půda- hornina. In: Kvitek, T. (ed.) a kol. Retence a jakost vody v povodívodárenskénádrže Švihov na Želivce. Povodí Vltavy, s. p. 2017, 1. vydání, s. 272, ISBN 978-80-270-2488-9.

[24] MARVAL, Š, HEJDUK, T, ZAUÍČEK, A VYBÍRAL, T, FUČ́́K, P, ROUB, R, a KAPLICKÁ, M Využit termografie jako nového prístupu pro identifikaci znečištění vod z bodových zdrojů - pozemn termografické snímkování. Vodní hospodárství, 2019, č. 6, roč. 69, s. 8-13. ISSN 1211-0760.

[25] FUČÍK, P., ZAJÍČEK, A., KAPLICKÁ, M., DUFFKOVÁ, R., PETERKOVÁ, J., MAXOVÁ, J., and TAKÁČOVÁ, S. Incorporating rainfall-runoff events into nitrate-nitrogen and phosphorus load assessments for small tile-drained catchments. Water, 2017, No. 9, p. 712. DOI: 10.3390/w9090712.

[26] TLAPÁKOVÁ, L., ČMELÍK, M., ŽALOUDÍK, J. a KARAS, J. Metodika identifikace drenážních systémú a stanoveni jejich funkčnosti. Pardubice: Výzkumný ústav meliorací a ochrany půdy, v. v. i., 2016. ISBN 978-80-87361-58-0.

\section{Autoři}

\author{
Ing. Štěpán Marval'1,2 \\ 凶marval.stepan@vumop.cz
}

Ing. Tomáš Hejduk, Ph.D.

四hejduk.tomas@vumop.cz

Mgr. Antonín Zajíček, Ph.D. ${ }^{2}$

凶zajicek.antonin@vumop.cz

Ing. Tomáš Vybíral, Ph.D. ${ }^{3}$

凶tomas.vybiral@georeal.cz

Ing. Radek Roub, Ph.D. ${ }^{1}$

凶roub@fzp.czu.cz

Mgr. Markéta Kaplická2

凶kaplicka.marketa@vumop.cz

'Fakulta životního prostředí, Česká zemědělská univerzita v Praze ${ }^{2}$ Výzkumný ústav meliorací a ochrany půdy, v. v. i.

${ }^{3}$ GEOREAL spol. s r. o.

Přispěvek prošel lektorským řízením.

DOI: 10.46555/VTEI.2020.03.004 


\section{IDENTIFICATION OF NON-POINT AGRI- CULTURAL POLLUTION USING THER- MOGRAPHIC IMAGING}

\section{MARVAL, S., ${ }^{1,2}$ HEJDUK, T. ${ }^{2}$; ZAJICEK, A. ${ }^{2}$; VYBIRAL, T. ${ }^{3}$; ROUB, R. ${ }^{1}$; KAPLICKA, M. ${ }^{2}$}

'Faculty of Environmental Sciences, Czech University of Life Sciences Prague ${ }^{2}$ Research Institute of Land Reclamation and Soil Protection, p.r.i.

${ }^{3}$ GEOREAL spol. s r. o.

Keywords: water quality - water temperature -

sources of pollution - agricultural drainage - drainage outlet

Water quality monitoring has a much shorter history in the Czech Republic (CR) than water quantity monitoring. Yet the quality of water resources is crucial for society, industry and agriculture. One of the most significant sources of water pollution is non-point agricultural pollution, transported mainly by agricultural drainage. Drainage runoff contributes to stream and river pollution especially with nitrates, pesticides and their metabolites, and potentially with other water-soluble (phosphate) compounds applied to agricultural land.

Agricultural drainage systems were built in the past to support and develop agriculture. Their tradition in the Czech Republic dates back to the end of the $19^{\text {th }}$ century, but most drainage systems were built in the period between 1960 and 1990. Drainage systems were usually built as systematic tile drainage with conducting drains discharged into main drainage facilities as single-purpose constructions for draining surplus water from the land. Recently, the negative effects of land drainage (eg. shrinking periods of time when water remains in the drained area, lowering the ground water table, and polluting shallow subsurface water with nitrates and pesticides) have been also considered, especially during periods of drought or rainstorms linked to climate change.

In order to design proper measures for the mitigation of such negative effects of drainage systems (e.g. drainage biofilters, constructed wetlands, regulation drainage systems, pools placed on outlets), precise knowledge about the location of tiles and outlets is required. One way to get this knowledge is to find, scan and ortho-rectify detailed construction plans. The issue with this approach is that many of these plans were lost during the huge economic and proprietorial changes (end of the socialist period) in the 90s. That's why surface thermography was tested as a new method for the identification of drainage outlets. It was assumed that drainage water and stream water would have different temperatures, especially during the winter season (drainage water is warmer than stream water) and in the summer (drainage water is colder than stream water). Monitoring water temperatures along the stream course allows for the identification of places with changed water temperature, which usually represent the drainage outlets location. Based on the results presented in this paper, it can be concluded that thermography is a useful method for identifying the locations of drainage outlets. 